\title{
Study of Protection Structures Planning for Krui Beach, Pesisir Barat Regency, Lampung Province
}

\author{
Nanda Nurisman ${ }^{1}$, Trika Agnestasia Tarigan ${ }^{2}$ \\ ${ }^{1}$ Ocean Engineering Department, Institut Teknologi Sumatera, South Lampung, Lampung \\ ${ }^{2}$ Ocean Engineering Department, Institut Teknologi Sumatera, South Lampung, Lampung
}

\begin{abstract}
Labuhan Jukung Beach is one of the beaches in Kru, which is located on Krui Bay, West Coast District. This beach is a tourist beach directly adjacent to the Indian Ocean, so it has a high wave. Based on wind data from 2008 - 2017 that be analyzed in this research, Krui Beach has extreme wave height (25th return period) as big as 6 meters in deep-sea water and $3.4 \mathrm{~m}$ in shallow water, consequently Krui Beach has the potential to erode To resolve these problems, must be built environmentally friendly coastal protection structure. The structure that can be used in this beach is groynes. Groynes serve as sediment traps and existence of groin does not disturb tourists who surf the beach. Based on HWS value and run-up wave calculation, the groin structure need to has elevation $+10.3 \mathrm{~m}$ from seabed, with armor weight is 6.3 ton
\end{abstract}

Keyword: Krui, erosion, groyn, coastal

\section{Introduction}

Lampung Province coast is $\pm 720 \mathrm{~km}$ long, covering the east coast which faces the Java Sea for \pm 300 $\mathrm{km}$, the south coast which facing the Lampung Bay and Semangka Bay for $\pm 130 \mathrm{~km}$ and $\pm 140 \mathrm{~km}$ respectively, and the west coast faces the Indonesian Ocean for $\pm 150 \mathrm{~km}$ (Sugito, 2014). According to Prayitno, et all (2000) has accurred erosion/abrasion and sedimentation in the Coastal Lampung Province. One of the coastal areas that have undergone an erosion process is Krui Beach.

Krui beach is a beach located in the west of Lampung Province. This beach is adjacent to the Indian Ocean that is potentially affected by swell waves from the ocean. Swell waves that are quite large and reach the shoreline can eroded sand on the shore and bring it towards the open sea, therefore, it can accelerate the beach abrasion process. In addition to natural factors, erosion or beach damage can also be caused by human activities which damage coastal protection plants.

Last October 11, 2017, $75 \mathrm{~km}$ of collapsed roads have occurred in KM 232 on the Krui-Biha, national road of Lampung, which is part of the western Sumatera road connecting Lampung and Bengkulu (http://finance.detik.com). The road is a west coastal crossing road (Jalan Lintas Barat) so that the collapse is made possible due to coastal erosion. According to Suwarsono et a., (2011) west coastal crossing road has a very vital role for land transportation, if this road damaged and cannot be passed by heavy vehicles, then it will greatly disrupt the economic acceleration of the local population. Based 
ICOSITER 2018 Proceeding Journal of Science and Applicative Technology

on these problems, in order to overcome erosion problems on the coast of Krui beach, studies to prevent erosion prevention which is widespread on Krui beach are needed. 


\section{Methodology}

\subsection{Study Site}

The research location is on Krui Beach, Pesisir Barat Regency, with approaching coordinate of $5^{\circ} 11^{\prime} 30.04^{\prime \prime}$ S $103^{\circ} 55^{\prime} 49.43^{\prime \prime} \mathrm{E}$. The location map and project layout can be seen in the following figures.

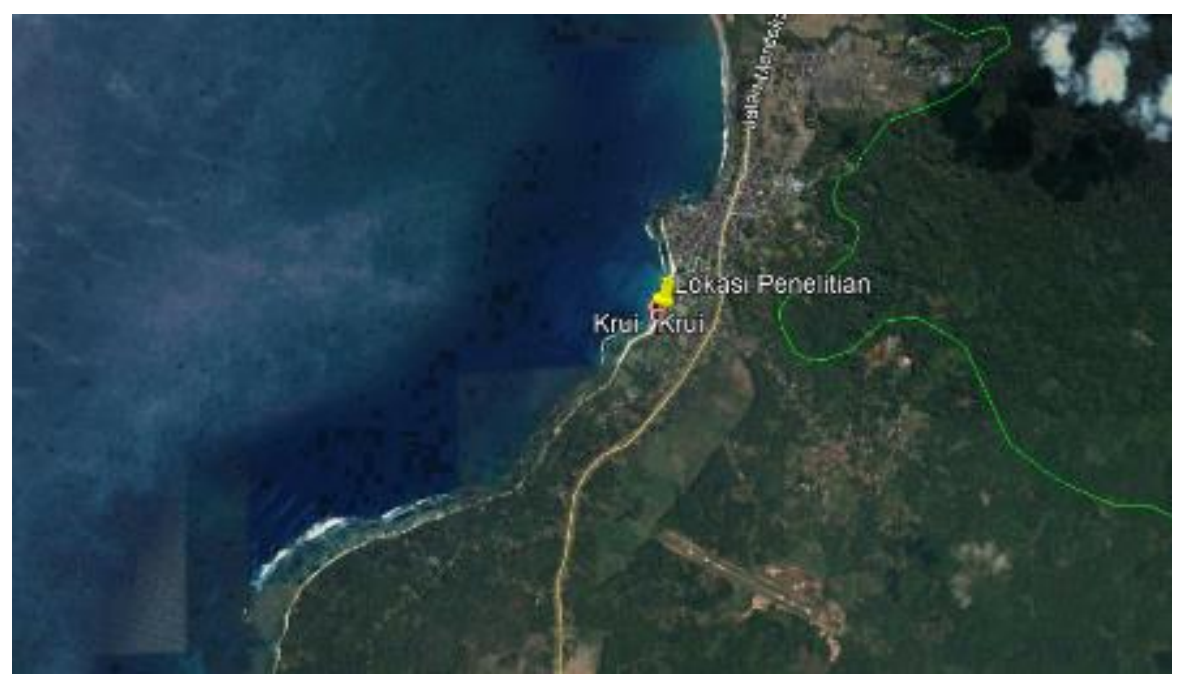

Figure 1. Krui Bay, Bandar Lampung Province (Source: Google Earth, access: February 12, 2018)

\subsection{Tidal Analysis}

Water level data (tidal data) in this study were obtained from the Badan Informasi Geospasial Department (BIG) with a data length of 30 days of observation. From tidal observation data, we can determine tidal constituents that are useful in predicting tidal elevation for 20 years to get the water level change especially the highest and lowest water level. Kisnarti, E.A and Viv D.P. (2014), tidal type can be determined by the formzahl number equation with using tidal constants

$$
F=\frac{K 1+O 1}{M 2+S 2}
$$

The type of tide could be one of the following:

$$
\begin{array}{ll}
F<0.25 & \text { semi-diurnal } \\
0.25<F<1.50 & \text { mixed (semi-diurnal dominant) } \\
1.50<F<3.00 & \text { mixed (diurnal dominant) } \\
F>3.00 & \text { diurnal }
\end{array}
$$

\subsection{Wave Analysis}

Wave prediction is calculated by hindcasting method. The main components used in hindcasting are Wind Data $\left(\mathrm{U}_{\mathrm{A}}\right)$ and Fetch Effective $\left(\mathrm{F}_{\text {eff }}\right)(\mathrm{SPM}, 1984)$. Wind data be used in this study was obtained from website of ECMWF. Fetch is an area of the formation of the wave which is assumed to have a relatively constant direction and wind speed. Effective fetch length calculation is done using the help of topographic maps with the location of a large enough scale, so it can be seen the islands or the mainland that affects the formation of the wave at a given location. Determination of the fetch point should be taken on the position of the deep ocean waters near the reviewed location. This is because the waves generated by the wind is formed at deep sea in the waters, and then propagates toward the shore and broke along with reduced depth near the shore. 


$$
\begin{gathered}
F e f f=\frac{\sum_{i=1}^{k} F_{i} \cos \alpha_{i}}{\sum_{i=1}^{k} \cos \alpha_{i}} \\
\frac{g x t}{U_{A}}=68.8 x\left(\frac{g x F_{\text {eff }}}{U_{A}^{2}}\right)^{\frac{2}{3}} \leq 7.15 x 10^{4} \\
H_{m o}=\frac{0.0016 x U_{A}^{2}}{g}\left(\frac{g x F_{\text {eff }}}{U_{A}{ }^{2}}\right)^{\frac{1}{2}} \\
T_{p}=\frac{0.2857 x U_{A}}{g}\left(\frac{g x F_{\text {eff }}}{U_{A}^{2}}\right)^{\frac{1}{3}}
\end{gathered}
$$

If equation (2) does not satisfy, then the incident wave is the result of the formation of the fully developed wave. Calculation of wave height and period using the following equations:

$$
\begin{aligned}
H_{m o} & =\frac{0.2433 x U_{A}^{2}}{g} \\
T_{p} & =\frac{8.134 x U_{A}}{g}
\end{aligned}
$$

If the results of a comparative analysis satisfy the above equation, the wave that occurs is the result of not fully developed wave generation. There are 2 (two) types of not fully developed wave generation, namely the fetch limited wave and duration limited wave. To distinguish between both, it needs to be known in advance the critical duration $\left(t_{c}\right)$, as follows :

$$
t_{c}=\frac{68.8 x U_{A}}{g}\left(\frac{g x F_{e f f}}{U_{A}^{2}}\right)^{\frac{2}{3}}
$$

If $t>t_{c}$, then the incident wave is fetch limited one. But, If $t<t_{c}$, then the incident wave is duration limited one, so first need to replace $F_{\text {eff }}$ to $F_{\min }$

$$
F_{\min }=\frac{U_{A}^{2}}{g}\left(\frac{g x t}{68.6 x U_{A}}\right)^{\frac{3}{2}}
$$

\subsection{Structure Design}

Banijamali, B, et al. (2016) the weight of the armor units of breakwater is determined using the Hudson equation:

$$
\begin{gathered}
W=\frac{\gamma_{r} H^{3}}{K_{D}\left(S_{r}-1\right)^{3} \cot \theta} \\
S_{r}=\frac{\gamma_{r}}{\gamma_{a}}
\end{gathered}
$$


Elevation of breakwater's crest is calculated based on run-up wave, that depend on wave characteristic, slope of structure, porosity, and roughness of breakwater's layer (Triatmodjo, B. 2011)

$$
\begin{gathered}
E l_{\text {structure }}=H W S+R_{u}+\text { freeboard } \\
H_{\text {Structure }}=E l_{\text {structure }}-E l_{._{\text {depthwater }}}
\end{gathered}
$$

\section{Results and Discussions}

\subsection{Tidal Analysis}

Based on tidal analysis, it is known that the tidal type in the study location is mixed (semi-diurnal dominant) with formzahl number $=0.29$. It's meant that in one day has flood tide and twice the ebb tide, but the height and period of water elevations are different. From the 20 years prediction data, HWS was obtained $172.17 \mathrm{~cm}$. For more detail of the important elevation are shown in the following table.

Tabel 1. Important tidal elevations of Krui Bay

\begin{tabular}{|l|r|}
\hline Important Tidal Reference Elevation (cm) \\
\hline Highest Water Spring (HWS ) & 172.17 \\
\hline Mean High Water Spring (MHWS) & 157.06 \\
\hline Mean High Water Level (MHWL) & 128.58 \\
\hline Mean Sea Level (MSL) & 93.65 \\
\hline Mean Low Water Level (MLWL) & 58.84 \\
\hline Mean Low Water Spring (MLWS) & 41.77 \\
\hline Lowest Water Spring (LWS ) & 30.95 \\
\hline
\end{tabular}

\subsection{Wave Analysis}

Wave height at the study site was predicted by extreme wave height propagation that obtained from hindcasting deep ocean waves using wind data from 2008 to 2017. The hindcasting method in this study used SPM method, cause based on the studied by Akpinar, A, et all (2014), SPM methode has good results in the hindcast of wave. According to hindcasting analysis, wave incident dominant come from Northwest, South and Southeast. Maximum wave height gets $5.6 \mathrm{~m}$ and extreme wave height for 25-years return periode is $6.04 \mathrm{~m}$ (Southeast). Following figures showing the distribution wave:

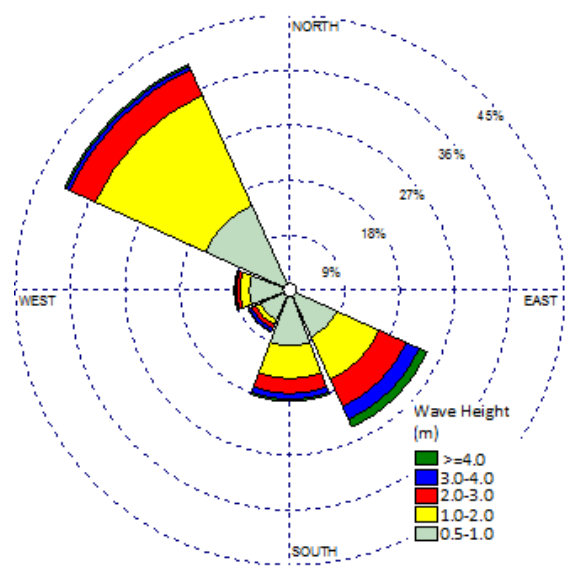

Figure 2. Wave Rose (2008-2017) 
Form extreme value analysis of deep-water wave height still cannot directly be used for design of coastal structure. Becasuse the wave spreading is influenced by sea bed contour where the wave movement will be transformed according to the bathymetric condition of the area. But in this study, there was no measurement of bathymetry, so bathymetry data is obtained from a sea map made by DISHIDROS. Extreme wave height and bathymetry data, then used in wave transformation simulation to get wave height in coastal area. Based on the results of the simulation of the wave obtained the wave height at the study location is $3.4 \mathrm{~m}$

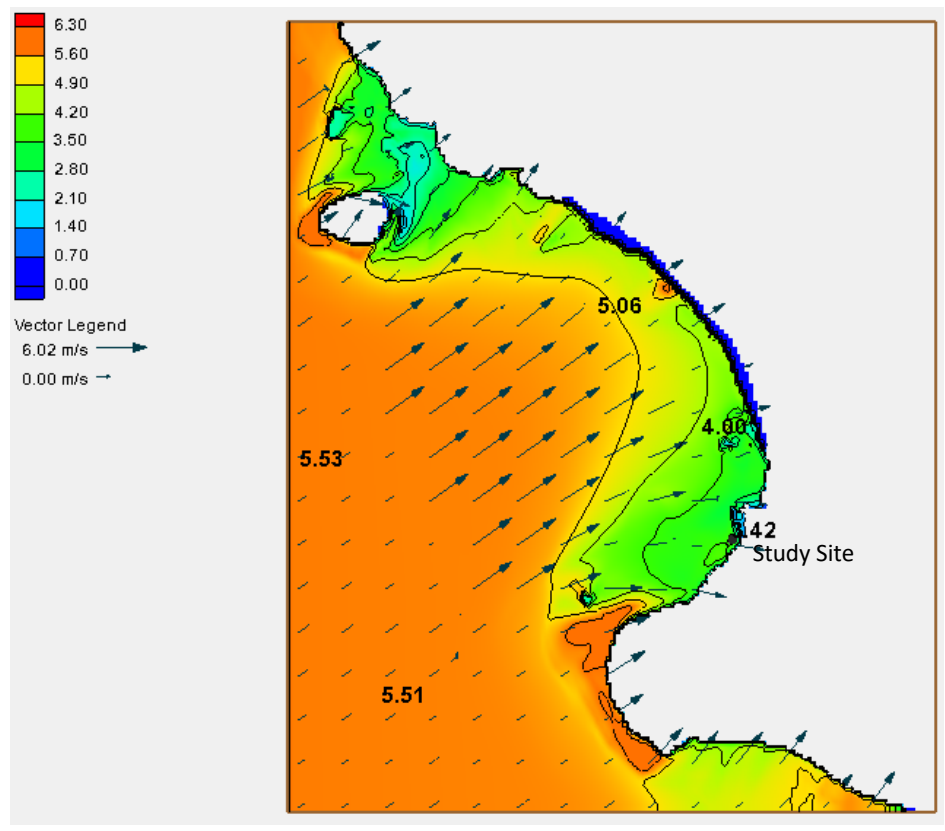

Figure 3. Wave Height in Study Site

\subsection{Structure of Design}

Jukung beach which is one of the tourist beaches in Krui. This beach has high waves, so many tourists come to surf. However high waves reaching the coast have the potential to cause coastal erosion. Based on coastal conditions, the beach protective structure that is suitable for the type of beach tourism is groin. Groin is narrow structure built out into the water from a beach in order to prevent beach erosion or to trap and accumulate sand that would otherwise drift along the beach face and nearshore zone under the influence of waves approaching the beach at an angle. Groynes serve as sediment traps and existence of groin does not disturb tourists who surf the beach.

Wave height at the study site is $3.4 \mathrm{~m}$ and the slope of the plan structure is $1: 2$. By using equation-13, it is known that the weight of the armor is 6.3 ton for the tetrapod type. Based on HWS value and run-up wave calculation, the groin structure need to has elevation $+10.3 \mathrm{~m}$ from seabed.

\section{Conclusion}

Krui Bay has mixed (semi-diurnal dominant) tidal type with formzahl number 0.29. Study site bordering the Indian Ocean has potentially affected by swell waves from the ocean which can cause erosion. Based on the beach condition where is a tourist beach, so the structure that is suitable is groin structure seriated. The armor weight of the tetrapod structure is 6.3 ton, with elevation structure groin is $+10.3 \mathrm{~m}$ from seabed 


\section{References}

A. Akpinar, et al., Performance Evalution of Parametric Models in The Hindcasting of Wave Parameters along The South Coast of Black Sea. Indian Journal of Geo-Marine Sciences Vol.43(6), 2014, pp. 905-920.

W. Daniel, (2017, October 13). Ada Jalan Amblas di Lampung, PUPR Kirim Jembatan Darurat. DetikFinance.[Online]. Available: https://finance.detik.com/infrastruktur/d-3681996/ada-jalanambles-di-lampung-pupr-kirim-jembatandarurat? ga=2.234207262.1096602689.1508296541-1461561100.1505716163.

E. A. Kisnarti and D. P. Viv, Methods of Tidal Approach for Determination of Sea Level Rise in Surabaya Waters. The IJES Vol.3, 2014, pp. 12-17.

Prayitno, et al., Rencana Strategis Pengelolaan Wilayah Pesisir Lampung. Pemerintah Daerah Provinsi Lampung. 2000.

Sugito, Analisa Perencanaan Bangunan Pemecah Gelombang Lokasi Teluk Semangka Kota Agung Kabupaten Tanggamus. Jurnal Teknik Sipil UBL Vol.5, 2014, pp.540-551.

Suwarsono, Supiyati and Suwardi, Zonasi Karakteristik Kecepatan Abrasi dan Rancangan Teknik Penanganan Jalan Lintas Barat Bengkulu Bagian Utara Sebagai Jalur Transportasi Vital. Makara Teknologi Vol.1, 2011, pp. 31-38. 